\title{
Microfinance: State-of-the-art Paradigm for Women's Empowerment in Bihar
}

\author{
Vishal Anand \\ (Research Scholar, IRRDM, MU, Bodh-Gaya, India)
}

\begin{abstract}
This paper is a study of various aspects of women's empowerment in Bihar. A number of scholars agree that microfinance is an effective tool of women's empowerment. An attempt has been made to assess Socio-economic impact of microfinance on empowerment of women. This paper also sheds light on the role of empowered women in their families and societies. The findings of this paper are based on secondary sources of data.
\end{abstract}

Keywords: Empowerment, Jeevika, microcredit, potential, transformative.

\section{Microfinance:-}

\section{Introduction}

Microfinance is provision of financial services for low-income people who traditionally lack access to banking and financial services. More broadly, it is a movement whose object is "a world in which as many poor and almost poor households as possible have permanent access to an appropriate range of high quality financial services, including not just credit but also savings, insurance and fund transfers." Promoters of microfinance believe that poor are not poor because they are inherently not able to support themselves but rather because they lack access to capital a structural economic defect which could be redressed.

Due to the success of microcredit, many in the traditional banking industry have begun to realize that these microcredit borrowers should more correctly be categorized as pre-bankable; thus, microcredit is increasingly gaining credibility in the mainstream finance industry, and many traditional large finance organizations are contemplating microcredit projects as a source of future growth, even though almost everyone in larger development organizations discounted the likelihood of success of microcredit when it was begun.

The importance of microfinance as a tool of poverty alleviation and women empowerment can be judged by the fact that the United Nations declared 2005 the International Year of Microcredit. The event highlighted microfinance as an instrument for socioeconomic development and women empowerment. The year was launched on November 18, 2004. The United Nations Economic and Social Council proclaimed the year 2005 as the International Year of Microcredit to call for building inclusive financial sectors and strengthening the powerful, but often untapped, entrepreneurial spirit existing in communities around the world.

\section{Empowerment of Women:-}

Even though women constitute a major part of the population they are challenged by a number of obstacles that restrict their ability to play significant roles in their families, communities and governance. They lack many of the resources available to their male counterparts. Traditionally social, political, cultural and economic barriers prevent women from accessing education and financial services which prevent their overall empowerment process. The women need extraordinary consideration to secure their empowerment and active participation in the decision making process. For a long time they have lagged far behind men in key socioeconomic indicators that place them at a huge disadvantage.

According to the World's Women 2010: Trends and Statistics which is fifth issue of the series World's Women two thirds of the 774 million adult illiterates worldwide are women, the same proportion for the past 20 years and across most regions.

According to “ 2010 Report: Women Entrepreneurs Worldwide” by Global Entrepreneurs Monitor women's participation in entrepreneurial activity varies widely around the globe, ranging from slightly more than $1.5 \%$ of women in the adult working age population (between ages 18 to 64 ) to as high as $45.4 \%$. The report was based on interviews with more than 90,000 women across 59 economies. Participation of women in entrepreneurship as compared to men is very low in most of the economies. In many economies female participation goes as low as a 1:10 ratio.

The access of women particularly those belonging to the rural areas to education, health and productive resources, among others, is inadequate at the grass root level although many research shows that the achievement of gender equality has enormous socio-economic implications. Occupational segregation and 
gender wage gaps continue to persist in all parts of the world. Therefore, they remain largely marginalized, poor and socially excluded.

Empowered women and girls have a truly transformative role to play in their families and societies but they are rarely given the opportunities that will allow them to fulfil their significant roles. Around the world educated, employed and empowered women break poverty cycles - not only for themselves, but for their families, societies and nation too.

Now-a-days in almost every developing nation emphasis is being laid on the need for empowerment of women and their effective presence in the mainstream development movement of these countries.

\section{Causes Of Backwardness Of Women In Bihar}

Bihar is one of poorest states in India and ranks very low as regards to different development indices. It is spread over an area of ninety four thousand square kilometres that is $2.8 \%$ of total area of the country and has $8 \%$ of the total population of the country within its territory. The average size of a land holding in the state is 0.58 hectare, which is half the all-India average of 1.57 hectare. Over 80 percent farms are very small with an average size 0.30 hectare, whereas small and marginal farms together constitute 91 percent of the total land holdings. Bihar also has the lowest levels of women's literacy and girls' school enrolment.

Traditional financial institutions supporting the availability of finance to the poor have not been able to perform up to the desired level in the state. Several attempts have been made to link the poor who are organized in the form of SHG's to the bank however these attempts have not been very successful. This situation had its adverse impact on the economic and social empowerment of women and economic and rural development of the state on the whole. All the credit needs of the poor have been fulfilled by money lender traditionally as a result of this most poor households in Bihar are chronically indebted to local moneylenders who charge interest at exorbitant rates of 4 to $14 \%$ monthly. Land and other productive assets are taken over by the moneylenders as collateral for the duration of the loan, which restrains the borrower's ability to repay. As per Reserve Bank of India estimate in 2006, in Bihar one bank existed for a population of 22,224. However, in the rest of India, there was one bank for a population of 15,000. The figures in Punjab, Maharashtra and West Bengal were even better with a bank existing for every 9,000, 11,000 and 14,000 persons respectively. The table below shows the share of institutional and non-institutional agencies in outstanding cash debt of major states. The shares of noninstitutional agencies have risen considerably and many reports show that they are doing a roaring transaction of over thousands of crores of rupees in the state. It has also become an easy source of money for many who just entered as intermediary to exploit the poor. In this dismal situation need was felt to do away with the traditional ways of making finance available to the rural masses and explore new possibilities of rural development and women empowerment.

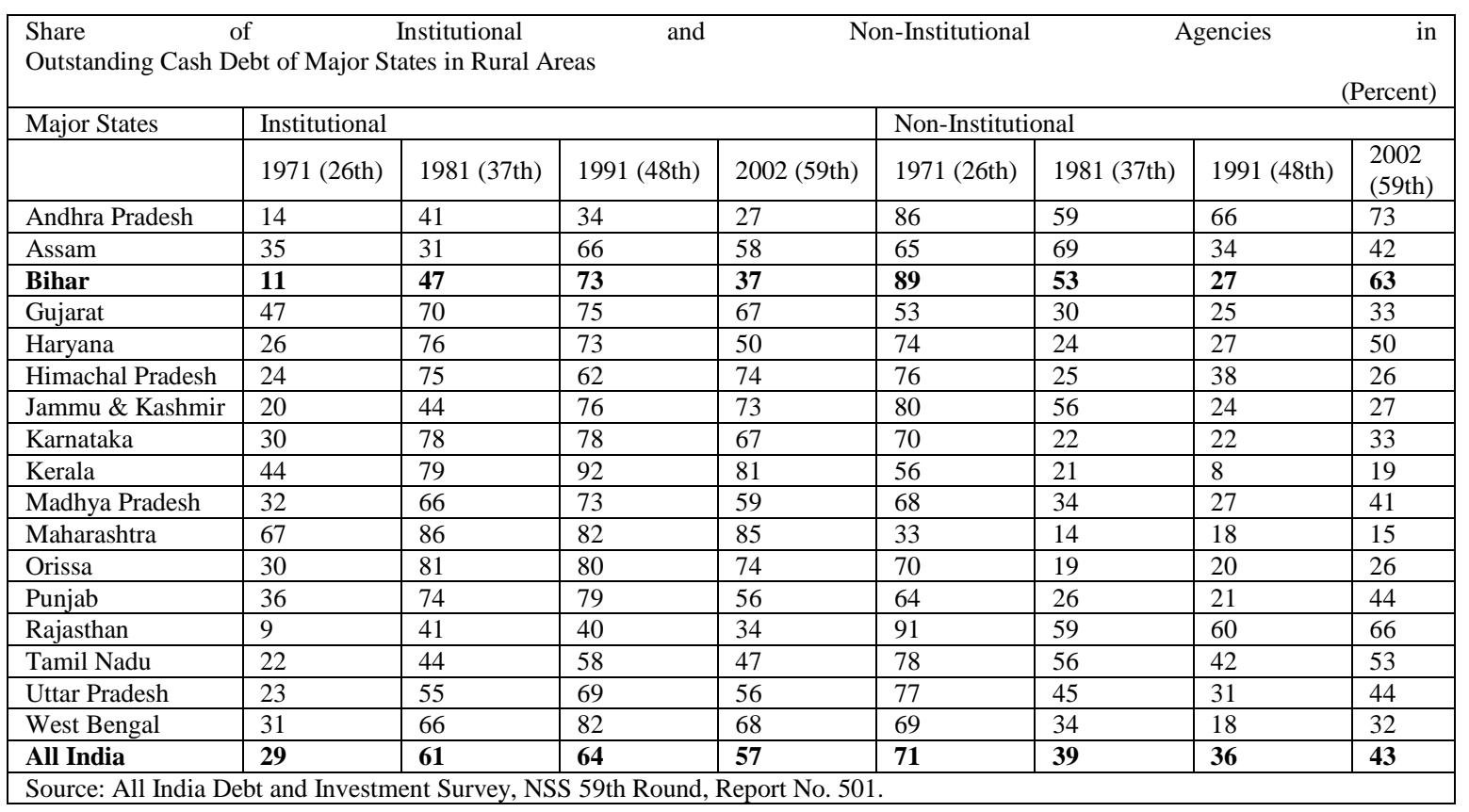


Grameen Bank:-

\section{Empowerment Of Women Through Microfinance}

Microcredit is a financial innovation that is generally considered to have originated with the Grameen Bank founded by Nobel laureate Mohammad Yunus, in 1983 in Bangladesh. It makes small loans known as microcredit to the impoverished without requiring collateral. The Bank's Low-cost Housing Program won World Habitat Award in 1998. In 2006, the bank and its founder, Mohammad Yunus, were jointly awarded the Nobel Peace Prize.

According to Mohammad Yunus poor have skills that are under-utilized, and with incentive, they can earn more money. A group-based credit approach is applied to use peer-pressure within a group to ensure the borrowers follow through and conduct their financial affairs with discipline, ensuring repayment and allowing the borrowers to develop good credit standing. The bank also accepts deposits and provides other services. As a result of bank's credit policy to support under-served populations $96.8 \%$ of the borrowers of Grameen Bank are women. It has successfully enabled extremely impoverished people mainly women to engage in selfemployment projects that allow them to generate income, build assets, exit poverty and thus empower themselves socially, economically and politically.

On a television interview with Nightly Business Report Mohammad Yunus was asked why he loaned primarily to women. He replied "it has to do with the decision to have a separate bank for the poor people. From the beginning, I had complained about the banking system on two grounds. One complaint was that the banking system was denying financial services to the poor people through certain rules it had set up. The second allegation was that the banking system also was not treating women fairly. If you look at the gender composition of all the borrowers of all the banks in Bangladesh, not even $1 \%$ of the borrowers happen to be women. I said this is a very gender biased organization. So when I began, I wanted to make sure half the borrowers in my program are women so that they are even. I did that. It was not easy because women themselves didn't think that they should borrow money. I had to do a lot of convincing. I encouraged them to believe that they can borrow money and make money. Part of that effort was to overcome fears, cultural fears and the fact that they had never had any experience with business and so on. Soon we saw that money going to women brought much more benefit to the family than money going to the men. So we changed our policy and gave a high priority to women. As a result, now 96\% of our four million borrowers in Grameen Bank are women.

\section{Bihar Rural Livelihood Project (Jeevika):-}

Taking cognizance of the enormity of problem in Bihar, the government of Bihar has initiated a project on rural livelihood promotion with support from the World Bank. This initiative is implemented through a Society registered with Government of Bihar by the name of Bihar Rural Livelihoods Promotion Society (BRLPS) or Jeevika. BRLPS through the Bihar Rural Livelihoods Project (BRLP) aims to improve rural livelihood options and works towards social and economic empowerment of the rural poor and women. The BRLP intervenes with the community through the following four themes or programmes: institution and capacity building, social development, microfinance and livelihood. The objective of the BRLP is to provide gainful self-employment opportunity for the skilled and semiskilled women in rural areas of Bihar by organising them into community groups, and thereby uplift them from their present poverty level. A primary objective of this project is to allow households to retire high-cost debt. This is expected to improve food security, allow accumulation of productive assets, and ultimately increase household income. In addition, the project aims to increase women's empowerment and capacity for collective action.

Jeevika provides affordable credit and agricultural training to women in rural Bihar through self-help groups. The programme was initiated in all the blocks of 6 districts, 3 blocks each from 12 new districts, and 1 block each from another 17 districts at the first phase in 2012-13. The rest of the blocks will be brought under this programme in 2013-14 in a phased manner.

Under this programme, 1.50 crore poor rural households will be organised into 10 lakh of Self-Help Groups (SHG), 65 thousand Village Organisations, 16 thousand Cluster Level Federations and 534 Block Level Federations. For the programme, 3 lakh Community Para-Professionals and 75 thousand Community Resource Persons will be identified and trained. It is expected that the total saving of these households would reach about Rs. 3100 crore. They will be able to get credit worth Rs. 5800 crore from the Community Investment Fund and Rs. 12,000 crore from the banks. Till now, 67.5 thousand SHGs, 4.6 thousand Village Organisations and 53 Cluster Level Federations have been organized, covering 8.62 lakh poor households. Out of the SHGs already organized, bank accounts of 53 thousand SHGs have been opened and 36.8 thousand SHGs have been financed by the banks. Apart from this, SHGs have received a credit of Rs. 176.8 crore from the commercial banks. In addition, 2.7 thousand Village Organisations have been provided with Food Security, and around 3 thousand of them have been provided with Health Security Fund. To ensure social security, 1.37 lakh and 1.42 lakh of households have been insured under National Health Insurance Scheme and Jan Surksha Bima Yojana respectively. For enhancing agricultural productivity, 2.14 lakh farmers have been trained in various modern 
crop techniques; for enhancing production in animal husbandry, 269 Milk Cooperatives have been organised, covering 10.5 thousand milk producers.

Jeevika has made a positive impact on poverty and women's empowerment in Bihar since its inception in October 2007. The project is expected to reach 1.25 crores mobilisation of women across Bihar by 2021. Jeevika provides affordable credit and agricultural training to women in rural Bihar through self-help groups (SHGs). Once an SHG has demonstrated the commitment of its members to contribute regular savings, and the capacity to keep records of these finances, it becomes eligible for access to an initial capitalization fund of Rs.50,000 (Rupees Fifty Thousand) for lending among its members. Additional interventions such as training in intensive farming and animal husbandry are also planned for targeted populations.

Better implementation of the programme will enhance the saving habit of the rural households and generate more livelihood opportunity for them. It will also be an instrument for women's empowerment. The association of the private sectors and NGOs with this programme is also planned for creating opportunities for value chains in traditional arts and crafts, incense sticks and honey and the like.

\section{Conclusions}

There still exists a wide gap between the goals enunciated in the policies and programmes of the government and the explicit status of women in Bihar. Empowerment of women is necessary not only for women themselves but also for the development of their family, society and country as a whole. This paper shows that Microfinance is an effective tool for the empowerment of women. Once a woman joins the microcredit program her level of empowerment increases rapidly. Those women who receive credit gain access to additional resources even if they are not investing the fund in income generating activities. Grameen bank has proved how microfinance can help rural women develop and empower themselves. It has helped women in Bangladesh to achieve social, political and cultural freedom. The impact of Grameen Bank is such that a greater percentage of women in Bangladesh now participate in decision making at social, political and economic life of the nation. BRLP has created a conducive environment in Bihar through its economic and social policies for development and empowerment of women and to enable them to realize their full potential. Beyond a shadow of doubt BRLP has succeeded in making women proactive inside as well as outside their households. In the last few years women in Bihar have come out of their shells and by their active participation and involvement have been able to change societal attitudes and community practices also. However gender disparities still exists which shows we have not yet achieved our ultimate goal. It is anticipated that till 2021 Jeevika will make substantial contribution to women's empowerment in Bihar.

\section{References}

[1]. Economic survey 2012-13 Government of Bihar, Finance Department.

[2]. All India Debt and Investment Survey, NSS 59th Round, Report No. 501

[3]. A Study on SHG-Bank Linkage and Status of MFI in Bihar: By Bhartiya Samruddhi Investments and Consulting Services Ltd. (BASICS Ltd)

[4]. http://www.brlp.in

[5]. 2010 Report: Women Entrepreneurs Worldwide by Global Entrepreneurs Monitor

[6]. The World's Women 2010: Trends and Statistics 